\title{
Diagnosis of Labor Relations and Human Capital Through the Prism of HR Branding
}

\author{
Svetlana Kochina ${ }^{1}{ }^{*}$ Elena Shchetinina ${ }^{2}$ \\ ${ }^{1}$ Belgorod State Technological University named after V.G. Shoukhov, Belgorod, Russia \\ ${ }^{2}$ Saint Petersburg State Technological Institute (Technical University), Saint-Petersburg, Russia \\ Email: swetakochina@yandex.ru
}

\begin{abstract}
The purpose of the article is to describe the principles of a new integrative methodological approach to the analysis of labor relations and corporate human capital (HC), an approach that would consider the multidimensionality of this category, namely, its relationship with social, marketing, economic and environmental aspects. The hypothesis is put forward and argued that it is advisable to carry out the analysis and formation of the $\mathrm{HC}$ and the corresponding labor relations based on HR branding as a tool of the integral direction of corporate marketing and management. In turn, it is based on the most progressive concepts of social and ethical marketing and the social responsibility of business at the moment. Based on this, it is proposed to diagnose such multidimensional indicators of the company's condition as labor, based on the elements of the HR branding structure as a management subsystem, assessing their presence and development in a particular corporation, the scale of investment in this area, efficiency and impact on performance. Thus, this integrative methodological approach will allow the company to identify weaknesses in its workforce and then develop measures to eliminate them and strengthen market positions based on the data obtained.
\end{abstract}

Keywords: Labor relations, Human capital, Integrativity, HR branding, HR management, Diagnostics of human capital.

\section{INTRODUCTION}

During its formation and development, labor and human resources management undergo significant changes - up to the methodological and instrumental crisis, like any other science. We agree with the prevailing opinion in scientific circles that the main reason for these phenomena is the lack of the necessary interdisciplinarity and complexity when considering problems at the micro and macro levels and developing solutions taking into account the dynamics of changes in internal and external factors.

Strategic directions of human capital (HC) management development are associated with integrativity and a holistic approach, and one of the manifestations of this direction is HR branding [1]. The authors of this article develop a methodological approach to diagnosing an enterprise (firm) and its labor relations through the prism of HR branding.
With this approach, labor productivity results from the development of HR branding and the company's market position - since the demand for its products depends on the loyalty of consumers and staff to the corporate brand [2].

To develop the methodological foundations of this approach, it is necessary to clarify what is meant by HR management, what are its basic principles and identify its essential elements.

\section{RESEARCH METHODOLOGY}

The system-holistic and dialectical approach, monographic method, method of theoretical generalisation and comparison, scientific abstraction, logical method, methods of induction and deduction, methods of grouping and generalisation were applied.

Our methodological premise is based on the axiomatic relationship between the employer's brand as 
an element of integrative marketing- on the one hand, and the quality of labor relations and human resources of the organisation, on the other. Many modern studies confirm this connection. Thus, E.A. Tereshchuk methodically links the measurement of the level of organisational culture with the quality of labor resources [3]. Researchers E. Flores, X. Xu and Y. Lu emphasise that industry 4.0. should also correspond to the human capital of version 4.0. [4]. As a management technology of the new time, approaches to HR branding were developed by M.A. Fedotova, I.V. Setyamin, N.A. Osovitskaya, S.A. Khromova, K.E. Levina, S. Barrow, R. Mosley, M. Schumann, L. Sartain, J. Robin, M. Burchell. In particular, we used theoretical provisions on forming a corporate HR branding system by V.N. Belkin, N.A. Belkina, O.A. Antonova [5], the model of the employer's value proposition by V.N. Pulyaeva [6], the refined definition of Ya.Yu. Chireeva HR brand as a human resource management tool [7]. Proposed by U. Itam, S. Misra and H. Anjum, management indicators based on the HR concept were considered [8], as well as works in this area by P. Banerjee, G.K. Saini and G. Kalyanaram [9] and H. Urbancova, M. Hudakova [10].

With this in mind, the methodological approach proposed by the authors was based on the composition analysis of the organisations' HR branding subsystem (example of the Belgorod region construction companies) and the selection on this basis of a set of the most significant indicators for a multidimensional assessment of human capital. Thus, human capital is considered the quality of labor relations regarding creating new value, taking into account the sociohumanistic concept of marketing.

\section{THE MAIN PART}

According to the most common view in scientific circles, human capital represents it is an investment in the development of an employee (specific and general) [11].

HR branding is a new stage of corporate marketing, which has a complex impact on resources, primarily human, and through them - on all others [12]. The fact is that the personnel of an enterprise (firm, corporation) is rightly considered today to be the driver of development, innovation, and efficiency.

The employer's brand and corporate culture are concepts of the same semantic series. The latter should play a vital role in forming a successful employer brand. At the same time, the former should consider and consolidate cultural nuances elements that make this company different from others. It is known that culture, as a way of transmitting and reducing knowledge and rules, holds any system, any organisation.

Employer branding provides an opportunity:
- identify and strengthen the key or system-forming fragments of the corporate culture, on which its overall image, style of behaviour, value for customers and partners depend;

- to form modern personnel for the corporation, with the necessary qualities and corporate patriotism;

- to make relevant changes to the company's corporate culture (enterprise) as its life cycle and the challenges of time and form its unique image.

Based on this, it is possible to identify several principles of HR branding:

1) the employer's brand must clearly reflect an individual organisation's cultural facts and factors, namely: its competitive advantages. These factors can both attract job seekers, partners, potential customers and turn out to be unattractive for them;

2) the employer's brand should motivate the staff for high-quality work, commitment to the company, ensure the self-esteem of the staff, the ability to use the intangible assets of the corporation, its connections, information base and other privileges.

Let's consider the employer's brand from the perspective of a potential or actual employee. It can be defined as a set of positive value associations about the company (enterprise) as a unique employer in the labor market. In other words, it is a complex of positive associations of an employee about an organisation's unique material and intangible values as an employer that distinguishes it in the labor market.

Figure 1 shows the structure of the employer's brand.

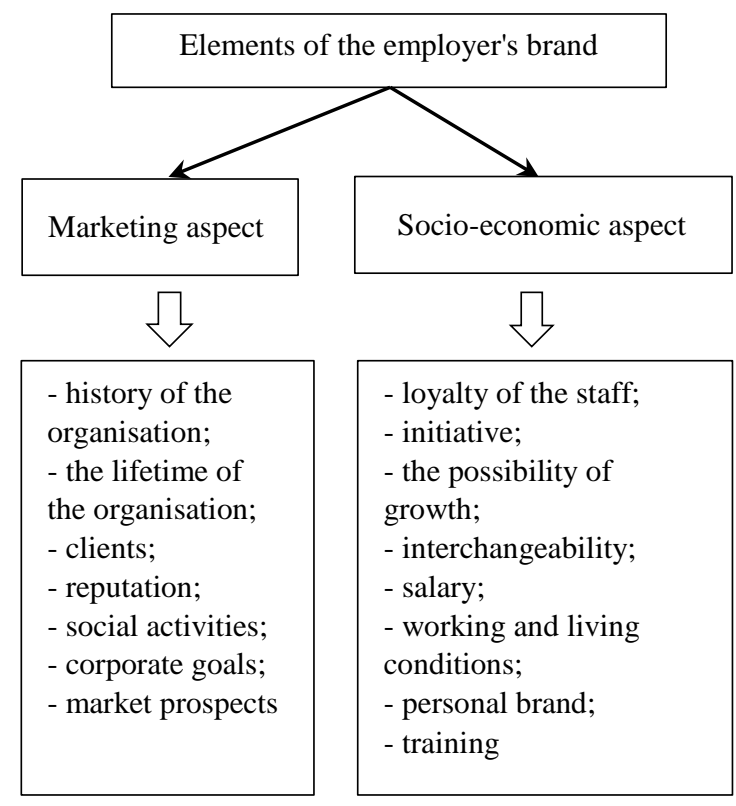

Figure 1 Employer's brand structure. 
The elements of the employer's brand are reflected in the human capital management system of the enterprise (company), which includes policies and measures aimed at a positive impact on employees.

These activities include selecting and recruiting employees, adapting and developing new and existing employees, staff bonuses, providing prospects for developing and implementing their knowledge and skills, and conducting experimental work toward their activities within a specific organisation.

An effectively functioning human capital management system should provide a set of unique and stimulating values aimed at increasing the organisation's attractiveness among new employees and retaining existing employees [13].

From the point of view of management, when setting up an HR branding system, one of the leading concepts is "Employee Value Proposition" (EVP) [14]. It is a key message about the value properties of the employer. This message includes an idea, memes, slogan, design, videos and other informative material based on a creative concept. Such a value proposition formulates arguments based on which the category of specialists interested in the employer should want to:

- to work in this company (the argument of attracting staff);

- work well (staff involvement argument);

- stay in this company for a long time (retention argument).

At first, it may seem that the "employee value proposition" and the employer's brand are identical concepts. This is not quite true: if there are common features, there is a fundamental difference.

The employer's brand is what the firm (enterprise) is known for. In another way, it is a "unique trade offer" of the organisation, which the head applies in contacting staff, customers, and partners. Ultimately, a successfully developed employer brand demonstrates the strength of its competitiveness and its place in a particular industry market.
The EVP parameter is directly related to the advantages and benefits that the organisation offers. Even though an effectively developed employer brand can attract potential employees, EVP, in turn, can convince candidates that they want to work in this organisation and the existing staff that they do not want to go anywhere [15].

The most acceptable option for the company's successful development is when the employer's brand and EVP complement each other.

\section{METHODS OF DIAGNOSTICS OF LABOR RELATIONS AND HUMAN CAPITAL}

The algorithm of such diagnostics consists of the following stages:

1. Selection of a set of private indicators (based on the analysis of the HR branding subsystem) or HR indices. For example, the company's history, the company's reputation, the presence of regular customers, market prospects, staff training, social protection, reviews of the company - both customers and staff, the possibility of a personal brand, etc. The method of calculating private indices is based on measurements, surveys, and investment in some aspects of the HR brand.

2. Scaling criteria for assessing labor relations and human capital (HC).

3. Evaluation of the organisation's human resources management (i.e. calculation of the integral

HR index), using the weighted average value principle.

4. Identification of the relationship between the elements of HR branding and labor indicators (labor productivity, wages, motivation, sales volume per 1 employee, staff satisfaction or other).

Let's present in Table 1 a list of the main HR indexes with an indication of their degree of importance (rank).

Table 1. Ranking of HR indexes

\begin{tabular}{|l|c|}
\hline \multicolumn{1}{|c|}{$\quad$ Name of the HR index } & Weight (Grade) \\
\hline Social protection & 0.12 \\
\hline Salary level & 0.11 \\
\hline Staff satisfaction & 0.18 \\
\hline Staff turnover & 0.16 \\
\hline The presence of regular clients & 0.21 \\
\hline Positive feedback about the company's activities & 0.2 \\
\hline
\end{tabular}


Table 2. The values of HR indices in comparison with the level of labour productivity

\begin{tabular}{|l|c|c|c|c|c|c|}
\hline \multicolumn{1}{|c|}{ Indicator } & "ZHBK-1" & "Vega" & $\begin{array}{c}\text { Stroy- } \\
\text { Design }\end{array}$ & «ROSKROV» & "Brik24" & $\begin{array}{c}\text { Transyuzh- } \\
\text { stroy }\end{array}$ \\
\hline Social protection & 1.08 & 0.6 & 0.84 & 0.48 & 0.72 & 1.2 \\
\hline Salary level & 1.1 & 0.66 & 0.88 & 0.55 & 0.77 & 1.1 \\
\hline Staff satisfaction & 1.62 & 0.54 & 1.08 & 0.9 & 1.26 & 1.8 \\
\hline Staff turnover & 1.28 & 0.96 & 0.64 & 0.8 & 0.64 & 1.28 \\
\hline $\begin{array}{l}\text { The presence of regular } \\
\text { clients }\end{array}$ & 1.89 & 0.84 & 1.05 & 1.26 & 1.05 & 1.68 \\
\hline $\begin{array}{l}\text { Positive feedback about } \\
\text { the company's activities }\end{array}$ & 1.6 & 1.4 & 0.8 & 1.2 & 0.6 & 1.8 \\
\hline Integral HR Index & 1.43 & 0.83 & 0.88 & 0.87 & 0.84 & 1.48 \\
\hline $\begin{array}{l}\text { Labour productivity, } \\
\text { thousands of rubles }\end{array}$ & 806.49 & 224.94 & 484.47 & 336.14 & 446.07 & 3066.67 \\
\hline
\end{tabular}

After determining the rank and setting the significance of the above indices (on a ten-point scale), it is necessary to calculate the integral HR index using the following formula:

$\mathrm{HR}_{\mathrm{I}}=\frac{\sum_{\mathrm{i}=1}^{\mathrm{n}} \mathrm{g}_{\mathrm{i}} \cdot \mathrm{r}_{\mathrm{i}}}{\mathrm{n}_{\mathrm{i}}}$

where $\mathrm{HR}_{\mathrm{I}}$ is the integral $\mathrm{HR}$ index, gi is the relative value of the $\mathrm{i}$-th private HR index, ri is the weight (rank) of the $\mathrm{i}$-th private HR index, ni is the number of private HR indices in the overall structure of the integral parameter.

Based on this, it is possible to designate the levels of the integral HR index: low (from 0 to 0.81 ); medium (from 0.82 to 1.3 ); high (1.31 to 1.7 ).

Table 2 shows the values of HR indices for several construction companies in the Belgorod region and labor resources indicators for 2020 .

From the presented calculations of private HR indices, there is a positive correlation between the integral index and labor indicators. This relationship can be traced by calculating the linear correlation coefficient:

$r=\frac{\sum x y-\frac{\sum x \sum y}{n}}{\sqrt{\left(\sum \mathrm{x}^{2}-\frac{\left(\sum \mathrm{x}\right)^{2}}{\mathrm{n}}\right) *\left(\sum \mathrm{y}^{2}-\frac{\left(\sum \mathrm{y}\right)^{2}}{\mathrm{n}}\right)}}$

where $r$ is the linear correlation coefficient; $x$ is the integral HR index; $y$ is labor productivity; $n$ is the number of analysed organisations.

The interpretation of the linear correlation coefficient is as follows:

- $r=0$ - no connection between the indicators;

$-0<r$; $--1<\mathrm{r}<0$ - the presence of feedback (with an increase in the value of $x$, the value of $y$ decreases, and vice versa);

- $r=1$ - there is a functional relationship, i.e. each value of the factor indicator strictly corresponds to one value of the effective indicator.

Having made all the necessary calculations, we get:

$r=\frac{5690.26-\frac{2.91 \cdot 5362}{6}}{\sqrt{\left(4.24-\frac{2.91^{2}}{6}\right) *\left(10646236-\frac{5362^{2}}{6}\right)}}=0,76$

The obtained value of the correlation coefficient demonstrates a direct relationship between the integral HR index and labor productivity.

\section{CONCLUSION}

Thus, an integrative marketing methodological approach to the diagnosis of labor relations and corporate human capital, implying an analysis of the HR branding of this enterprise, can be used as a tool in the competitive struggle. To assess the management of the organisation's human resources, the approach of calculating the integral HR index is justified. Also, a close relationship between labor productivity and the integral HR index was revealed by calculating the linear correlation coefficient. I.e. with an increase in the value of this index, the level of labor productivity will increase. Which, in the end, will have a positive impact on the organisation's activities.

\section{REFERENCES}

[1] M.A. Eskindarov, Yu.M. Gruzina, I.A. Firsova, M.V. Melnichuk, Human capital competencies in high-tech and knowledge-intensive sectors of the 
economy, Economic and Social Changes: Facts, Trends, Forecast 13(6) 2020 199-214. DOI: https://doi.org/10.15838/esc.2020.6.72.12

[2] E.D. Shchetinina, N.V. Dubino, Balanced scorecard as a basis for managing the competitiveness of construction enterprises in the region [Sbalansirovannaya sistema pokazatelej kak osnova upravleniya konkurentosposobnost'yu stroitel'nyh predpriyatij regiona], Bulletin of BSTU named after V.G. Shukhov [Vestnik BGTU im. V.G. SHuhova] 11 (2017) 218-225. DOI: https://doi.org/10.12737/article 5a001ac85c0583.5 1773455

[3] E.A. Tereshchuk, Issues of measuring the effectiveness of organisational culture in the context of personnel management [Voprosy izmereniya effektivnosti organizacionnoj kul'tury $\mathrm{v}$ kontekste upravleniya personalom], Society and Power [Socium i vlast'] 6(86) (2020) 55-66. DOI: https://doi.org/10.22394/1996-0522-2020-6-55-66

[4] E. Flores, X. Xu, Y. Lu. Human Capital 4.0: a workforce competence typology for Industry 4.0, Journal of Manufacturing Technology Management 31(4) (2020) 687-703. DOI: https://doi.org/10.1108/JMTM-08-2019-0309

[5] V.N. Belkin, N.A. Belkina, O.A. Antonova, Theory and Practice of the employer's HR brand [Teoriya i praktika HR-brenda rabotodatelya], Bulletin of the South Ural State University. Series: Economics and Management [Vestnik YUzhno-Ural'skogo gosudarstvennogo universiteta. Seriya: Ekonomika i menedzhment] 13(4) (2019) 156-166. DOI: https://doi.org/10.14529/em190416

[6] V.N. Pulyaeva, The employer's value proposition role in forming the HR brand [Rol' cennostnogo predlozheniya rabotodatelya $\mathrm{v}$ formirovanii HRbrenda], Economics, Entrepreneurship and Law [Ekonomika, predprinimatel'stvo i parvo] 10(3) (2020) 659-676. DOI: https://doi.org/10.18334/epp.10.3.100591

[7] Ya.Yu. Chireeva, HR brand as a human resource management tool [HR-brend kak instrument upravleniya chelovecheskimi resursami], Topical Issues of Modern Economy [Aktual'nye voprosy sovremennoj ekonomiki] 5 (2019) 637-641. DOI: https://doi.org/10.34755/IROK.2019.5.5.114

[8] U. Itam, S. Misra, H. Anjum, HRD indicators and branding practices: a viewpoint on the employer brand building process, European Journal of Training and Development 44(6/7) (2020) 675694. DOI: https://doi.org/10.1108/EJTD-05-2019$\underline{0072}$
[9] P. Banerjee, G.K. Saini, G. Kalyanaram, The role of brands in recruitment: mediating role of employer brand equity, Asia Pacific Journal of Human Resources 58(2) (2020) 173-196. DOI: https://doi.org/10.1111/1744-7941.12209

[10] H. Urbancova, M. Hudakova, Benefits of employer brand and the supporting trends, Economics \& Sociology 10(4) (2017) 41-50. DOI: https://doi.org/10.14254/2071-789X.2017/10-4/4

[11] P.M. Wright, Rediscovering the "Human" in strategic human capital, Human Resource Management Review 31(4) (2021) 100781. DOI: https://doi.org/10.1016/j.hrmr.2020.100781

[12] N.L. Gryaznova, N.A. Pleshkova, G.A. Podzorova, A.V. Mukhacheva, G.S. Drapkina, Diagnostics of the state of the enterprise's human capital and the directions of its development [Diagnostika sostoyaniya chelovecheskogo kapitala predpriyatiya i napravleniya ego razvitiya], Bulletin of Kemerovo State University. Series: Political, Sociological and Economic Sciences [Vestnik Kemerovskogo gosudarstvennogo universiteta. Seriya: Politicheskie, sociologicheskie i ekonomicheskie nauki] 6-2 (20) (2021) 191-197. DOI: https://doi.org/10.21603/2500-3372-2021-62-191-197

[13] O.P. Krupskyi, Y. Kuzmytska, Organisational culture and business strategy: connection and role for company survival, Central European business review 9(4) (2020) 1-26. DOI: https://doi.org/10.18267/j.cebr.241

[14] K. Harsch, M. Festing, Dynamic talent management capabilities and organisational agilitya qualitative exploration, Human resource management 59(1) (2020) 43-61. DOI: https://doi.org/ 10.1002/hrm.21972

[15] E.K. Torosyan, O.A. Tsukanova, K.S. Meshova, Analysis of the main trends and development methods of the human resource management system [Analiz osnovnyh tendencij i metodov razvitiya sistemy upravleniya chelovecheskimi resursami], St. Petersburg Economic Journal [Peterburgskij ekonomicheskij zhurnal] 4 (2019) 34-41.

DOI: https://doi.org/10.25631/PEJ.2019.4.34.41 